\title{
Bioaccessibility and Speciation Study of Iron in Bovine Tissue
}

\author{
da Silva, I. J. G. ; Fonseca, L.; Costa, A. C. dos S.; Moita, G. C.
}

Rev. Virtual Quim., 2017, 9 (2), 476-491. Data de publicação na Web: 27 de março de 2017

\author{
http://rvq.sbq.org.br
}

\section{Estudo da Bioacessibildade e Especiação de Ferro em Tecido Bovino}

\begin{abstract}
O$ teor de ferro total e ferro bioacessível foram determinados em carne através da espectrofotometria na região do visível pelo método da 1,10-fenantrolina. As amostras foram cozidas, desidratas e algumas preparadas como carne de sol. Elas foram submetidas a uma simulação da digestão gastrointestinal para a avaliação da bioacessibilidade de ferro. Entre as amostras analisadas, o coração e fígado apresentaram os maiores teores de ferro total e bioacessível. Após o cozimento, houve um aumento da bioacessibilidade do ferro. $O$ fígado e 0 coração contribuíram respectivamente com 28 e $20 \%$, em termos de bioacessibilidade. A inserção da bioacessibilidade em tabelas de composição de alimentos é importante, pois se trata de informações nutricionais mais próximo da realidade. Foi possível quantificar o teor de $\mathrm{Fe}^{2+} \mathrm{em}$ todas as amostras analisadas, no entanto, o $\mathrm{Fe}^{3+}$ só foi quantificado na amostra de carne de sol cozida e nas amostras de coração. $O$ método empregado não foi sensível para à detecção do ferroheme e observou-se que houve um aumento do ferro iônico com o cozimento devido à liberação do ferro a partir do complexo heme.
\end{abstract}

Palavras-chave: Carne; ferro; bioacessibilidade; especiação.

\section{Resumo}

The content of total iron and total bioaccessible iron were determined in beef through visible spectrophotometry by the method of 1,10-Phenanthroline. The samples were cooked, dehydrated and prepared as jerked beef. They were submitted to a simulation of gastrointestinal digestion for the evaluation of bioaccessibility. Among the samples analyzed, the heart and the liver had the highest levels of total iron and total bioaccessible iron. After cooking the samples, there was an increased bioaccessibility of iron. The cooked liver and heart contributed respectively with $28 \%$ and $20 \%$ in terms of bioaccessibility The insertion of bioaccessibility in food composition tables is important, as it comes to nutritional information closer to reality. It was possible quantify the amount of $\mathrm{Fe}^{2+}$ in all samples, however, only $\mathrm{Fe}^{3+}$ was quantified in samples of cooked sun meat and in the samples of heart. The method was not sensitive enough to detect the heme iron and it was observed that an increase of ionic iron with cooking due to liberation of iron from the heme complex.

Keywords: Meat; iron; bioaccessibility; speciation.

\footnotetext{
* Universidade federal do Piauí, Chemistry Department, Natural Sciences Center, CEP 64049-550, Teresina-PI, Brazil.

$M$ igor.jg@gmail.com

DOI: $10.21577 / 1984-6835.20170027$
} 


\section{Bioaccessibility and Speciation Study of Iron in Bovine Tissue Igor José G. da Silva, * Lorenna Fonseca, Ana Cristina dos S. Costa, Graziella C. Moita}

Universidade federal do Piauí, Chemistry Department, Natural Sciences Center, CEP 64049-

550, Teresina-PI, Brazil.

*igor.jg@gmail.com

\section{Introduction}

\section{Experimental Part}

\subsection{Equipment}

2.2. Reagents and solutions

2.3. Samples

2.4. Preparation of samples

2.5. Preparing the solutions of samples for determining the total iron

2.6. Preparing the soluble fraction: in vitro digestion

2.7. Preparing the solutions of samples for determining the bioaccessible total iron

2.8. Speciation - Determining Ionic Iron $\left(\mathrm{Fe}^{2+}+\mathrm{Fe}^{3+}\right)$

2.9. Speciation - Determining $\mathrm{Fe}^{2+}$

2.10. Speciation - Determining $\mathrm{Fe}^{3+}$

2.11. Speciation - Determining heme Fe

2.12. Limits of detection and quantification

2.13. Accuracy

\section{Results and Discussion}

\section{Conclusions}

\section{Introduction}

A healthy diet must be composed of a variety of nutrient and diet fibers sources in adequate proportions. Nutrients such as proteins, carbohydrates, lipids, vitamins and minerals are essential for the growth and maintenance of tissues and organs, i.e., they are fundamental for the physiological and metabolic processes of our organism. ${ }^{1}$

Iron is an essential nutritional element for all life forms; from among its functions in the human metabolism, some stand out, for example, oxygen transport and storage; it works on the conversion of ribose into desoxyribose; it is a co-factor of some enzymatic reactions; it works on the electrons transport, and several other metabolic functions. ${ }^{2}$ Although the iron daily 
requirements are 8 and $18 \mathrm{mg}$ for man and woman, respectively, this element is potentially toxic when excessive, due to its pro-oxidant activity. Therefore, its concentration in food samples should be frequently controlled. ${ }^{3}$

The iron deficiency is the most prevalent dietary deficiency in humans, characterizing the so-called iron-deficiency anemia. ${ }^{4}$ It is estimated that $50 \%$ to $90 \%$ of all types of anemia worldwide occur due to the lack of this nutrient, with $54.9 \%$ prevailing among pre-school children, $29.1 \%$ in pregnant women and $23.1 \%$ in women of reproductive age. ${ }^{5,6}$

This deficiency has significant consequences for the human health in general and for the developing child in particular, and, in the most affected countries, this problem may result in a negative economic impact. Thereby, the efforts to improve the absorption of this micronutrient are a priority in the field of public health worldwide. ${ }^{7}$

The diet of populations from developing countries is usually low in micronutrients, especially iron. ${ }^{8}$ This situation may occur from the low intake of this nutrient or from the intake of foods with low bioavailable iron. ${ }^{9}$

Iron, which is found in a large variety of foods, may appear in the diet in two forms, each one having different pathways of intestinal absorption. The non-heme (ionic iron) is present in vegetables and dairy products, whereas the heme is present in food from animal tissues. ${ }^{7}$ As regards these forms of iron, it has been observed that more than $15 \%$ of heme ingested is absorbed by the organism in comparison with the nonheme, of which less than $5 \%$ is absorbed. ${ }^{10-12}$

In order to analyze the dietary quality and sources of minerals it is necessary to accurately define the quantity of minerals available for absorption and use, i.e., the bioavailability, which has attracted interest in nutritional studies. ${ }^{13}$ This term is used to describe the proportion of a nutrient in a food that can be used for the normal functions of the organism. ${ }^{14,15}$

There are dietary factors that lead to the increase of the iron absorption by forming complexes with this element in the intestinal lumen, remaining soluble in the digestion process. On the other hand, there are dietary factors that inhibit the iron absorption by promoting its polymerization and/or precipitation or they may bond to the iron forming complexes that do not release the metal for the mucosa receptors. ${ }^{16,17}$ Although these many factors may affect the nutrients' absorption, the soluble (or dialyzable) fraction has been considered bioavailable, which, at least theoretically, is available in the organism, even that other factors may hinder the access to these nutrients. ${ }^{13}$ Thus, it is important to know and understand the mechanisms involved in the increase or inhibition of the iron absorption by several dietary factors. ${ }^{16}$

There are in vivo and in vitro methods that may be used to estimate the bioavailability of iron. The in vitro techniques enable the estimate of the availability of inorganic elements considered essential. This method can quantify the soluble or dialyzable capacity of the nutrient, but not the availability of this proper, as not all soluble or dialyzable material is absorbed. The major advantages of the method are to enable the best control of variables, being an important model to predict and suggest new in vivo studies and the low methodological cost. However, this method shows as disadvantage the fact of not reproducing most of the physiological factors involved in the absorption and use of the nutrient, but the pieces of information attained are more significant than determining the total of minerals in the food. ${ }^{13}$

Therefore, this method - in addition to its advantages - may be regarded as an important precursor for studies involving only the quantity of mineral available in the gastrointestinal tract for absorption, that is, the bioaccessibility. ${ }^{13}$

From among the best known sources of iron are animal viscera (liver, heart, gizzard 
etc.), followed by meats in general (fowl, beef, fish, among others), milk and dairy products, vegetables, whole-grain cereals and some dark-green leaves (cauliflower, broccoli, wild chicory). ${ }^{18,19}$

The meat consumption may be a good manner to qualitatively and quantitatively respond to the human nutrition mineral requirements. Some reports published show that red meat is an important source of minerals for the human diet, and it provides the essential minerals, of a high bioavailability. ${ }^{20}$

Red meat contains high biological value protein and important micronutrients that are necessary for a good health throughout our lifetime. It also contains a variety of fats, including polyunsaturated omega 3 that is essential. ${ }^{21}$ However, nutritional changes may occur in the different types of meats, due to the breed and age of the animals, feeding, geographical location of breeding and processing, and even, these nutritional changes may be verified by observing several parts of the same animal. ${ }^{22,23}$ Thereby, it is recommended that our diet be composed of foods from several groups (meats, milk and dairy products, fruits, vegetables and cereals). ${ }^{24}$

Several techniques/methods have been used to determine the different forms of iron in foods, including ion-exchange chromatography coupled to size-exclusion chromatography ${ }^{8}$, reversed-phase chromatography coupled to UV detection, ${ }^{23}$ liquid-liquid microextraction and flame atomic absorption spectroscopy, ${ }^{26}$ inductively coupled plasma - atomic emission spectrometry and inductively coupled plasma-mass spectrometry, ${ }^{27}$ UV-visible spectrophotometry, ${ }^{13}$ synchrotron $X$-ray fluorescence microscopy mapping and $X$-ray absorption near-edge structure (XANES) imaging, ${ }^{28}$ high-resolution continuum source flame atomic absorption spectrometry technique (HR-CS FAAS), ${ }^{29}$ ion chromatography spectrophotometry (ICVis), ${ }^{30}$ capillary electrophoresis, ${ }^{31}$ and flow injection diode array spectrophotometry and flame atomic absorption spectrometry (FIDAD (vis)-FAAS). ${ }^{32}$

Thus, this work aimed to estimate the bioaccessibility and the speciation of iron through the in vitro method simulating the gastrointestinal digestion in samples of bovine tissue commercialized in the city of Teresina, state of Piauí, using the UV-visible spectrophotometry.

\section{Experimental Part}

\subsection{Equipment}

For the assessment procedures of the in vitro digestion, a pH-meter (Marconi, PA 200) was used, as well as a Dubnoff water bath shaker (Quimis, Q226M2), a centrifuge (Nova instruments, NI1812) and a heating plate (IKA ${ }^{\circ} \mathrm{RH}$ basic 1 ). In preparing the samples aiming at the analyses of total and bioaccessible iron, digestion tubes and the block digestion system were used (Marconi, COM 45). The masses were weighed on a digital analytical balance (Denver Instrument APX 200), and the spectrophotometric measurements were carried out in a doublebeam molecular absorption spectrophotometer (Varian, Cary 300 Conc). For the dehydration of the samples, an kiln was used (Model 515-FANEM) and the water used throughout the process was purified by the GFL 2008 system.

\subsection{Reagents and solutions}

All the solutions were prepared using purified water and the reagents had a P.A. purity degree. The reference solutions for obtaining the analytical curve were prepared diluting a stock solution of $100 \mathrm{mg} \mathrm{L}^{-1}$ ammonium iron (II) sulfate (Vetec), in the concentration interval of 0.03 to $5.0 \mathrm{mg} \mathrm{L}^{-1}$ $\mathrm{Fe}^{2+}$. 
For determining iron, we used: $0.25 \%$ 1,10-phenanthroline (Vetec), $1 \mathrm{~mol} \mathrm{~L}^{-1}$ sodium acetate (Vetec), 1\% hydroxylamine hydrochloride (Synth).

The in vitro digestion was carried out using $37 \%$ hydrochloric acid (Merck), sodium bicarbonate (Synth), sodium hydroxide in lentils (Synth), $0.39 \%$ sodium nitrite solution (Synth), a precipitant solution of proteins obtained through the mixture of $10 \mathrm{~g}$ trichloroacetic acid (Synth) and $10 \mathrm{~mL}$ concentrated hydrochloric acid (Merck) diluted to $100 \mathrm{~mL}$ and the enzymes: bile salt (B8756 - Sigma-Aldrich), swine's gastric mucosa pepsin (P7000 - Sigma-Aldrich), swine's pancreas pancreatin (P7545 - SigmaAldrich).

For the preparation of the pepsin solution (gastric digestion), $0.12 \mathrm{~g}$ pepsin were weighed and dissolved to $2.5 \mathrm{~mL}$ of a $0.1 \mathrm{~mol}$ $\mathrm{L}^{-1} \mathrm{HCl}$ solution. The pancreatin-bile salt solution (intestinal digestion) was obtained by the mixture of $0.06 \mathrm{~g}$ pancreatin and 0.375 $\mathrm{g}$ bile salt, dissolved to $15 \mathrm{~mL}$ sodium bicarbonate $0.1 \mathrm{~mol} \mathrm{~L}^{-1}$.

\subsection{Samples}

All the samples were acquired in a local supermarket in the city of Teresina, state of Piauí. The samples were: the round cut, heart and liver.

\subsection{Preparation of samples}

At first, the samples were cleaned by removing their skin and cover fat, then a part was analyzed in natura by means of the gastrointestinal digestion for assessing the bioaccessibility, another part was dehydrated and ground in a blender (Walita, Liqfaz 082) and another was cooked and then also dehydrated and ground.

Approximately $30 \mathrm{~g}$ of the samples were weighed, in triplicate, in Petri dishes and taken to the incubator for dehydration for $2 \mathrm{~h}$ at $105 \pm 2{ }^{\circ} \mathrm{C}$; after this period, the dishes were removed and put to be cooled in a desiccator until they reached the room temperature, and then the whole set was weighed. This procedure was repeated every $2 \mathrm{~h}$ until a constant mass was obtained, for determining the humidity content. Next, the dried sample was ground in a blender and stored in an adequately shut polypropylene flask.

Approximately $200 \mathrm{~g}$ of each bovine cut was cooked in a beaker at $100{ }^{\circ} \mathrm{C}$ for $30-40$ min using $300 \mathrm{~mL}$ of purified water, which was added by small amounts during the cooking. After the cooking and total evaporation of the water, a part of this sample was dehydrated for determining the total iron according to the procedure described in the item Preparing the solutions of samples for determining the total iron. The other part was used in the bioaccessibility assay.

For the preparation of the sum dried meat [jerked meat], the round cut sample was sliced in thin layers; these were put into a plastic container and fine-ground cooking salt was spread over both sides of the cut. This was put to rest for $12 \mathrm{~h}$, next the meat was hung on a clothesline, in the shade, for $48 \mathrm{~h}$. After this period, it was divided into three parts: one was dehydrated, another was cooked and the other part was submitted to the later bioaccessibility assays.

\subsection{Preparing the solutions of samples for determining the total iron}

In digestion tubes, $0.5 \mathrm{~g}$ (triplicate) of the dehydrated and ground sample were weighed. To each tube $4 \mathrm{~mL}$ nitric acid were added, under room temperature. After resting for one night, the tubes were heated in a block digestion system $\left(80-100{ }^{\circ} \mathrm{C}\right)$ for nearly $3 \mathrm{~h}$ and $30 \mathrm{~min}$, for reducing the acid volume. Next, $1 \mathrm{~mL}$ perchloric acid was added and the temperature was gradually increased until it reached $200{ }^{\circ} \mathrm{C}$, proceeding with the digestion until ceasing the formation of $\mathrm{NO}$, 
$\mathrm{CO}_{2}$ and water vapor emanated from the tube. Afterwards, $20 \mathrm{~mL}$ deionized water were added, as well as $2.5 \mathrm{~mL}$ hydroxylamine hydrochloride (1.0\%), $2.5 \mathrm{~mL} \quad 1,10-$ phenanthroline $(0.25 \%)$ and $5.0 \mathrm{~mL}$ sodium acetate $\left(1.0 \mathrm{~mol} \mathrm{~L}^{-1}\right)$, and then the volume was completed with deionized water, correcting the volume in a $50 \mathrm{~mL}$ volumetric flask. After $15 \mathrm{~min}$, the spectrophotometric analysis was carried out in $510 \mathrm{~nm} \lambda_{\max }$.

2.6. Preparing the soluble fraction: in vitro digestion

For the in vitro digestion, the procedure suggested by Cámara $(2005)^{13}$ was adapted. In polypropylene flasks $(100 \mathrm{~mL}), 30 \mathrm{~g}$ of the in natura or cooked sample was weighed, in triplicate, to which $45 \mathrm{~mL}$ purified water were added, obtaining a suspension whose $\mathrm{pH}$ was adjusted to 2.0 with $6 \mathrm{~mol} \mathrm{~L}^{-1}$ hydrochloric acid. After $15 \mathrm{~min}$ the $\mathrm{pH}$ was verified and, when necessary, it was adjusted again. The gastric digestion started with the addition of $500 \mu \mathrm{L}$ pepsin solution, and then this mixture was incubated for $2 \mathrm{~h}$, at $37 \pm 0.5^{\circ} \mathrm{C}$, under Dubnoff water bath shaking.

By the end of this incubation period, the $\mathrm{pH}$ was verified again and adjusted to 5.0 with a $1.0 \mathrm{~mol} \mathrm{~L}^{-1} \mathrm{NaHCO}_{3}$ solution. For the intestinal digestion, $3.2 \mathrm{~mL}$ of the pancreatinbile salt solution were added and the tube was incubated again for additional $2 \mathrm{~h}$, at 37 ${ }^{\circ} \mathrm{C} \pm 0.5{ }^{\circ} \mathrm{C}$, under shaking. The intestinal digestion ceased leaving this system for 10 min in cooling bath. In this final stage, the $\mathrm{pH}$ was adjusted to 7.2 with a $0.5 \mathrm{~mol} \mathrm{~L}^{-1} \mathrm{NaOH}$ solution. Next, the digested sample was centrifuged at $3500 \mathrm{rpm}$ for $1 \mathrm{~h}$. By the end of that, the supernatant (soluble fraction) was transferred to $50 \mathrm{~mL}$ polypropylene tubes and the volume was completed with purified water.

\subsection{Preparing the solutions of samples} for determining the bioaccessible total iron

The same procedure previously described in the item Preparing the solutions of samples for determining the total iron was followed; by using in this case $5 \mathrm{~mL}$ of the soluble fraction for determining the bioaccessible iron. For in vitro results, the bioaccessible iron concentrations for the stomach and intestinal digestion were calculated by dividing the metal ions' concentrations measured in the in vitro gastric or intestinal phase solutions by the total iron concentration as described by the following equation:

$$
\text { In vitro bioaccesseble iron }(\%)=\frac{[\text { in vitro bioaccessible iron }]}{[\text { total iron }]} \times 100
$$

2.8. Speciation - Determining Ionic Iron $\left(\mathrm{Fe}^{2+}+\mathrm{Fe}^{3+}\right)$

An aliquot part of $5 \mathrm{~mL}$ of the soluble fraction was transferred to a polypropylene tube $(15 \mathrm{~mL})$, and $0.4 \mathrm{~mL}$ sodium nitrite $0.39 \%), 2.5 \mathrm{~mL}$ of the precipitant solution of protein and water were added to it, until completing $15 \mathrm{~mL}$. After the incubation at 100 ㅇ $\mathrm{C}$ for $10 \mathrm{~min}$, the material was centrifuged at $3300 \mathrm{rpm}$ for $15 \mathrm{~min}$. Five (5) $\mathrm{mL}$ of supernatant were transferred to $10 \mathrm{~mL}$ volumetric flasks and $2.5 \mathrm{~mL}$ of the hydroxylamine hydrochloride solution (1\%) and $2.5 \mathrm{~mL}$ of the 1,10-phenanthroline solution $(0.25 \%)$ were added; after a $15 \mathrm{~min}$ interval for developing the color, the absorbance measurement was carried out in $510 \mathrm{~nm} \lambda_{\max }$.

\subsection{Speciation - Determining $\mathrm{Fe}^{2+}$}


An aliquot part of $5 \mathrm{~mL}$ of the soluble fraction was transferred to a polypropylene tube $(15 \mathrm{~mL})$, and $0.4 \mathrm{~mL}$ sodium nitrite $0.39 \%), 2.5 \mathrm{~mL}$ of the precipitant solution of protein and water were added to it, until completing $15 \mathrm{~mL}$. After the incubation at 100 oC for $10 \mathrm{~min}$, the material was centrifuged at $3300 \mathrm{rpm}$ for $15 \mathrm{~min}$. Five (5) $\mathrm{mL}$ of supernatant were transferred to $10 \mathrm{~mL}$ volumetric flasks and $2.5 \mathrm{~mL}$ of the $1,10-$ phenanthroline solution $(0.25 \%)$ were added; after a 15 min interval for developing the color, the absorbance measurement was carried out in $510 \mathrm{~nm} \lambda_{\max }$. In this case, the absence of hydroxylamine hydrochloride solution ensures that only $\mathrm{Fe}^{2+}$ was complexed.

\subsection{Speciation - Determining $\mathrm{Fe}^{3+}$}

The $\mathrm{Fe}^{3+}$ was estimated by the difference between the concentration of the ionic iron and the concentration of the $\mathrm{Fe}^{2+}$.

\subsection{Speciation - Determining heme Fe}

The heme $\mathrm{Fe}$ was estimated by the difference between the concentration of the bioaccessible total iron of the mineral and the concentration of the ionic iron.

\subsection{Limits of detection and quantification}

For determining the limits of detection (LOD) and quantification (LOQ), ${ }^{33}$ a total of 21 measurements of the sample's blank value were carried out, and then the limits were calculated from the following formulas: $L o D=\frac{5 \times \sigma_{\text {Blank }}}{i}$ and $\quad L o Q=\frac{10 \times \sigma_{\text {Blank }}}{i}$, where $\sigma_{\text {Blank }}$ is the standard deviation of the blank and $i$ is the inclination of the analytical curve.

\subsection{Accuracy}

The accuracy was assessed in terms of recovery through the standard addition method. ${ }^{34}$ Known quantities of $\mathrm{Fe}^{2+}$ standard were added to the samples in three concentration levels, low $\left(1.00 \mathrm{mg} \mathrm{L}^{-1}\right)$, medium (2.00 $\left.\mathrm{mg} \mathrm{L}^{1}\right)$ and high (3.00 $\left.\mathrm{mg} \mathrm{L}^{-1}\right)$, and the same procedure for preparing the sample previously described for determination of iron total and bioaccessible iron was followed. The solutions of the sample with no addition of standard and each one of the samples with the standard added (estimated concentration) were analyzed and the recovery was expressed in terms of percentage of the measured quantity of the substance as regards the quantity added to the matrix. In this assay, the sample used was cooked liver.

\section{Results and Discussion}

Considering the importance of iron in the diet of the world population, the speciation in this work consisted in determining iron forms $\left(\mathrm{Fe}^{2+}, \mathrm{Fe}^{3+}\right.$ and heme) to obtain information on how these species are distributed in the bovine tissues studied. In addition to determining and evaluating the soluble fraction of this nutrient, which is the amount of iron that can be absorbed by the gastrointestinal tract of the human organism. Thus, the main stages of analysis in this study are the following: determinating total iron (wet digestion), digestion in vitro (simulation of gastrointestinal digestion); obtaining the soluble fraction; determinating of bioaccessible iron and iron speciation.

The calibration of the method was carried out from the analytical curve obtained in $\mathbf{5 1 0}$ $\mathrm{nm} \lambda_{\max }$. The calibration parameters are found in Table 1. 
Table 1. Calibration parameters for determining iron

\begin{tabular}{|c|c|c|c|c|c|}
\hline Nutrient & Straight-line equation & $r$ & $\begin{array}{c}\lambda_{\max } \\
(\mathrm{nm})\end{array}$ & $\begin{array}{l}\text { LoD } \\
\left(\mathrm{mg} \mathrm{L}^{-1}\right)\end{array}$ & $\begin{array}{l}\text { LoQ } \\
\left(\mathrm{mg} \mathrm{L}^{-1}\right)\end{array}$ \\
\hline Total iron & & & & 0.08 & 0.26 \\
\hline $\begin{array}{l}\text { Total bioaccessible } \\
\text { iron }\end{array}$ & $A=0.20968 C-0.00365$ & 0.9999 & 510 & 0.04 & 0.15 \\
\hline $\mathrm{Fe}^{2+}, \mathrm{Fe}^{3+}$ and heme & & & & 0.03 & 0.11 \\
\hline
\end{tabular}

$r$-correlation coefficient; LoD - limit of detection; LoQ - limit of quantification

A method allows obtaining precisely and accurately adequate results when it has a linear response directly proportional to the concentration of the analyte in the sample within a specified interval. ${ }^{34,35}$ As it can be seen from Table 1, the methods showed good linear responses within the chosen working range ( 0.03 to $5.0 \mathrm{mg} \mathrm{L}^{-1} \mathrm{Fe}^{2+}$ ), which can be proved by the linear correlation coefficient that showed a value higher than those recommended by INMETRO ${ }^{35}$ [National Institute of Metrology, Quality and Technology] of 0.9 or by ANVISA ${ }^{34}$ [National Health Surveillance Agency], which is 0.99, and that, therefore, the results attained will have reliable precision and accuracy. Furthermore, the limits of detection and quantification (Table 1) for all types of iron are lower than the concentrations of the solutions of the analyses studied herein.

As samples, in this study, commonly consumed cuts of bovine tissue were used, which are very complex and the analyte concentration is low; additionally, the meat has skin and fat that were separated whenever possible, but the inner fat was unable to be removed so that part of the matrix integrity was maintained; thus, the samples were ground to make them as homogeneous as possible, as in a chemical analysis one of the important conditions is homogeneity of samples, in order that one small fraction of it be a representation of the whole. $^{36}$
Accuracy refers to how close the measure value is to the actual value. It is an important parameter to evaluate not only the heterogeneity degree of the sample but also the extent of the losses that may occur during the process performed for the analyzes. In this case, the accuracy was verified from the recovery of added standard (Table 2), in order to check the losses regarding the processes to which the samples were submitted.

The results of the accuracy assay carried out in three concentration levels and in triplicate, using the samples of cooked liver (Table 2), revealed that the methods showed recoveries within the range established by ANVISA (80-120\%) indicating that the method is exact; ${ }^{34}$ and the relative standard deviations (RSDs) were lower than 5\%.

The recoveries for determining total iron ranged from 94 to $96 \%$, similar to the bioaccessibility recoveries of the soluble fraction (94 to 97\%), seen that the preparation of this latter solution involved a larger number of stages and addition of more reagents due to the gastrointestinal simulation, and despite that, for this sample these factors did not contribute to significant losses regarding the added standard, indicating that the sample was quite homogeneous and that there was no interference from the reagents in the process. 
da Silva, I. J. G. et al.

Table 2. Accuracy test for the analysis method

\begin{tabular}{|c|c|c|c|c|c|}
\hline Sample & Level & $\begin{array}{c}\text { Concentration of } \\
\text { the standard of } \\
\text { added iron } \\
\left(\mathrm{mg} \mathrm{L}^{-1}\right)\end{array}$ & $\begin{array}{l}\text { Concentration of } \\
\text { the standard of } \\
\text { recovered iron } \\
\left(\mathrm{mg} \mathrm{L}^{-1}\right)\end{array}$ & $\begin{array}{c}\text { Recovery } \\
\text { (\%) }\end{array}$ & $\begin{array}{l}\text { RSD } \\
\text { (\%) }\end{array}$ \\
\hline \multirow{3}{*}{ Cooked liver } & Low & 1.00 & 0.96 & 96 & 3.9 \\
\hline & Medium & 2.00 & 1.89 & 94 & 4.7 \\
\hline & High & 3.00 & 2.86 & 95 & 4.3 \\
\hline \multirow{3}{*}{$\begin{array}{c}\text { Cooked liver } \\
\text { (soluble fraction) }\end{array}$} & Low & 1.00 & 0.97 & 97 & 3.5 \\
\hline & Medium & 2.00 & 1.90 & 95 & 4.1 \\
\hline & High & 3.00 & 2.83 & 94 & 4.6 \\
\hline
\end{tabular}

RSD - relative standard deviation

Since in the daily diet the meat consumption is accomplished in its cooked form, the same analyses were carried out using the samples in this form of preparation to assess whether the cooking procedure somehow alters the iron content in the samples.

Table 3 shows the results for determining total and total bioaccessible iron for all the samples analyzed.

Table 3. Contents of total iron and total bioaccessible in in natura bovine tissue cuts

\begin{tabular}{|c|c|c|c|c|}
\hline Samples & $\begin{array}{c}\text { Total Iron } \\
\mathrm{mg} / 100 \mathrm{~g} \text { (RSD \%) }\end{array}$ & $\begin{array}{c}\text { Total Bioaccessible } \\
\text { Iron } \\
\mathrm{mg} / 100 \mathrm{~g}(\mathrm{RSD} \%) \\
\end{array}$ & $\begin{array}{c}\text { Humidity } \\
\text { (\%) }\end{array}$ & $\begin{array}{c}\% \text { of Total } \\
\text { Bioaccessible } \\
\text { Iron } \\
\end{array}$ \\
\hline Round cut & $2.45(0.5)$ & 0.46 (8.9) & 74 & 19 \\
\hline $\begin{array}{c}\text { Cooked round } \\
\text { cut }\end{array}$ & $3.85(0.2)$ & $0.72(8.2)$ & 62 & 19 \\
\hline Sum dried meat & $4.15(2.4)$ & $0.36(5.4)$ & 62 & 9 \\
\hline $\begin{array}{l}\text { Cooked sum } \\
\text { dried meat }\end{array}$ & $4.16(2.6)$ & 0.45 (4.9) & 55 & 11 \\
\hline Liver & $4.92(2.6)$ & $1.03(3.0)$ & 73 & 21 \\
\hline Cooked liver & 6.69 (1.0) & $1.87(5.0)$ & 58 & 28 \\
\hline Heart & $6.00(2.8)$ & $1.03(13.0)$ & 78 & 17 \\
\hline Cooked heart & $6.54(0.4)$ & $1.27(9.2)$ & 66 & 20 \\
\hline
\end{tabular}

RSD - relative standard deviation, $n=3$

The data referring to the total iron content (Table 3) are corrected taking into account the relative humidity of each sample (Table 3), as, for this analysis, the dehydrated sample was used, whereas for determining the total bioaccessible iron the in natura samples were used.

According to Table 3, the humidity in the in natura samples were around $73 \%$, while for the cooked samples, it was around $62 \%$. 
Analyzing the results shown in Table 3 , and comparing the samples among each other, it can be seen that there was an increase in the iron concentration when the samples were cooked; this occurs because with the cooking process, there was a loss of water, as the cooked samples showed a lower humidity content, resulting then in the preconcentration of the analyte. And, as the increase was not proportional to the humidity variation of each sample, the nonuniform distribution of the aggregates of the analyzed samples is evidenced.

It can be seen that the deviations obtained for determining the total iron were low (Table 3), but for the quantification of bioaccessible iron the RSDs were higher; this is because the concentration of the soluble fraction is low and due to the very heterogeneity observed in some samples, as in the case of the round cuts and heart samples. The other reason for such high deviations is in the method of analysis itself, one which consists of numerous steps causing loss of the analyte during transfer steps for example.

By comparing the results of total iron of the samples and their preparation manner, it can be observed that they are all statistically different (t-test, $\mathrm{p}=0.05$ ) and these differences of total iron concentrations among the samples seen in Table 3 are due to several factors affecting the quantity of iron present in the meat, e.g., cattle breeding, age, gender, type of muscular fiber, presence of fat, the samples' humidity content, and even the very distribution of nutrients all over the parts of the animal. ${ }^{37}$ It must be remembered that the manipulation of the meat as from the cut to the acquisition of the sample is also responsible for the variations in the iron content, due to the blood loss. This variation in the total iron content in bovine meat is reported in the literature, showing results of $2.2 \mathrm{mg} / 100 \mathrm{~g}^{38}$ and $3.4 \mathrm{mg} / 100 \mathrm{~g} .{ }^{39}$

Another factor to be regarded is the fat content in the cuts studied. The round cut has around $8 \mathrm{~g} / 100 \mathrm{~g},{ }^{40}$ while the liver shows
$4 \mathrm{~g} / 100 \mathrm{~g} .{ }^{41}$ With that, the iron content was expected to be lower in the round cut than in the liver, as for the same mass there is less material that contains iron, which is confirmed by the results obtained (Table 3 ), and besides, the liver is a very irrigated organ and concentrates the largest part of ferritin, a globular protein that accumulates the intracellular iron protecting the cell from the toxic effects of the free metal constituting a quickly mobilizable iron reserve. Similarly to the liver, the heart is also regarded as viscera, and it shows $4 \mathrm{~g} / 100 \mathrm{~g} \mathrm{fat},{ }^{42}$ and it is a very irrigated organ, plus it was the one to show the highest iron content, as it can be seen in Table 3.

The sum dried meat was prepared from the round cut, but the latter showed lower iron content (Table 3); this is due to two factors. Firstly, the cooking salt was used for preparing the meat, which, according to the product package, has sodium ferrocyanide as an anti-humectant (anti-moisturizing) agent, but the quantity added was not informed. Secondly, the major objective in preparing the sum dried meat is providing a better storage due to its dehydration, with that the humidity decreases - which was $74 \%$ in the round cut and $62 \%$ in the sum dried meat and, consequently, the iron preconcentration in the sum dried meat occurred.

By observing the samples of cooked round cut and sum dried meat (Table 3), it can be seen that both samples show the same humidity content, which is $62 \%$, and according to the t-test $(p=0.05)$ the results shown are statistically alike, which leads us to confirm that the difference found out is related to the sodium ferrocyanide antihumectant present in the cooking salt.

A more relevant piece of information from the nutritional viewpoint is the quantity of iron present in the meat likely to be absorbed, i.e., bioaccessible. ${ }^{13}$ The results obtained after the gastrointestinal digestion simulation are found in Table 3. 
It is observed that the treatment used for preparing the sum dried meat led to a decrease in the iron bioaccessibility, as the percentage obtained for the round cut $(19 \%)$ was higher than that for the sum dried meat (11\%). Still comparing the samples of cooked round cut and sum dried meat, both have the same humidity content ( $t$-test, $p=0.05$ ) (Table $4)$; as a consequence, until the carne-de-sol preparation, in which dehydration is only superficial, however, it can be observed that the bioaccessibility difference is possibly due to the structural differences occurred in the cooking process.

From among the samples analyzed, the ones showing higher bioaccessible iron content were the cooked liver $1.87 \mathrm{mg} / 100 \mathrm{~g}$ (Table 3), which corresponds to $28 \%$ of the total present in the sample and the cooked heart $1.27 \mathrm{mg} / 100 \mathrm{~g}$ corresponding to $20 \%$ of total bioaccessible iron, and from the cuts studied, these were the best two sources of iron.

Comparing the results of the samples among each other, as regards the cooking process, it can be observed that there was an increase of the iron availability in samples of round cut and liver ( $t$-test, $p=0.05$ ). This is due to the fact that in this cooking process reactions occurred affecting the solubility of the mineral studied; additionally, depending on the temperature and the exposure time to the cooking procedure, the protein denaturation may occur, compromising thus the iron available in the system..$^{20,43}$

Despite the indications provided by the in vitro method, in order to have a better understanding of the bioavailability of iron it is necessary to carry out a complementation of the studies through the in vivo technique. In vitro systems lack the ability to simulate absorption of the analyte through the walls of the intestine, as well as, provide an overall assessment of how the nutrient interacts with the various substances and organs that make up the human organism, besides not evaluating synergistic effects due to the presence of other elements.

Taking into account the results discussed here on the bioaccessibility of iron in bovine tissue and the existing information on the bioaccessibility of other elements in foods in the various scientific studies already published, it is interesting to show the great importance of inserting the bioaccessibility of nutrients into tables of nutrient composition of food in order to provide nutritional information closer to reality.

It is known that the heme is the most bioavailable form of iron with absorptions ranging from $10 \%$ to $30 \%$ and the bioavailability of the non-heme ranges from $1 \%$ to $20 \%$ due to many intra- and extraluminal factors that affect its intestinal absorption; ${ }^{6,44,45}$ it is important, thereby, to know the composition of its types in the foods.

For the chemical speciation, a precipitant solution of proteins and trichloroacetic acid was used to assure the heme to precipitate while the ionic iron remained soluble, sodium nitrite $\left(\mathrm{NaNO}_{2}\right)$ to stabilize the iron bound to the porphyrin ring of the heme group, and hydroxylamine hydrochloride for the reduction of free $\mathrm{Fe}^{3+}$ into $\mathrm{Fe}^{2+} \cdot{ }^{13}$ In Table 4 the results for the speciation of iron in meat are found.

According to Table 4, it was possible to quantify the $\mathrm{Fe}^{2+}$ in all samples and this form of iron was more soluble and less likely to hydrolysis under the conditions present in the gastrointestinal lumen; whereas the $\mathrm{Fe}^{3+}$ was only quantified in the cooked sum dried meat samples and heart samples. The results prove that $\mathrm{Fe}^{2+}$ is more likely to be absorbed by the organism than $\mathrm{Fe}^{3+}$ that is more affected by the intra- and extraluminal conditions. ${ }^{6,44,45}$ 
Table 4. Contents of $\mathrm{Fe}^{2+}, \mathrm{Fe}^{3+}$ and heme in in natura bovine tissues

\begin{tabular}{ccccc}
\hline Samples & $\begin{array}{c}\text { Ionic Iron } \\
\left(\mathrm{Fe}^{2+}+\mathrm{Fe}^{3+}\right) \\
\mathrm{mg} / 100 \mathrm{~g}(\mathrm{RSD} \%)\end{array}$ & $\begin{array}{c}\mathrm{Fe}^{2+} \\
\mathrm{mg} / 100 \mathrm{~g} \\
(\mathrm{RSD} \%)\end{array}$ & $\begin{array}{c}\mathrm{Fe}^{3+} \\
\mathrm{mg} / 100 \mathrm{~g} \\
(\mathrm{RSD} \%)\end{array}$ & Heme \\
\hline Round cut & $0.5(8.9)$ & $0.6(5.9)$ & $\mathrm{Nd}$ & $\mathrm{nd}$ \\
Cooked round cut & $0.7(8.2)$ & $0.7(5.1)$ & $\mathrm{Nd}$ & $\mathrm{nd}$ \\
$\begin{array}{c}\text { Sum dried meat } \\
\text { Cooked sum dried } \\
\text { meat }\end{array}$ & $0.4(5.4)$ & $0.3(3.8)$ & $0.1(5.3)$ & $\mathrm{nd}$ \\
Liver & $0.5(4.9)$ & $0.5(1.7)$ & $\mathrm{Nd}$ & $\mathrm{nd}$ \\
$\begin{array}{c}\text { Cooked liver } \\
\text { Heart }\end{array}$ & $1.0(3.0)$ & $1.0(4.3)$ & $\mathrm{Nd}$ & $\mathrm{nd}$ \\
Cooked heart & $1.9(5.0)$ & $1.9(7.4)$ & $\mathrm{Nd}$ & $\mathrm{nd}$ \\
& $1.3(13.0)$ & $0.9(12.0)$ & $0.2(9.5)$ & $\mathrm{nd}$ \\
\hline
\end{tabular}

RSD - relative standard deviation; $n d$ - non-detectable, $n=3$

Still regarding the $\mathrm{Fe}^{2+}$ and $\mathrm{Fe}^{3+}$, their prevalence can be associated to the characteristic color of the bovine tissue. The pigment myoglobin is the major responsible for the color of meat, which is constituted of a protein (the globin) and a non-protein part (the heme group); in it, the chemical status of the central atom of iron is what determines this hue. With its reduced form $\left(\mathrm{Fe}^{2+}\right)$ the color of meat is shown red (oxymyoglobin), with its oxidized form $\left(\mathrm{Fe}^{3+}\right)$ the color of meat is shown brown (metmyoglobin). ${ }^{46}$

From among the samples, the liver and the heart showed a deeper red color, when compared to the round cut, and this characteristic color evidences the presence of $\mathrm{Fe}^{2+}$. The results shown in Table 4 confirm this perception, in which the liver and heart samples showed the highest contents of $\mathrm{Fe}^{2+}$.

However, the method used in this study was not sensitive enough for detecting the heme (Table 4), and this form of iron is the most bioavailable from among all other forms.
For the spectrophotometric determination of chemical species in the visible region, it is usually necessary to use reagents that convert the species of interest into a form that allows the measurement of radiation absorption with greater sensitivity and / or selectivity. Thus, weakly absorbing species can be converted into compounds with higher molar absorptivity, aiming at the determination of smaller amounts of the analyte.

Cámara (2005) and collaborators carried out a work for the iron speciation in foods from school menus, among them, some containing meat in their composition, and for that they used as a complexing agent the bathophenanthroline that has a twofold molar absorptivity $\left(22350 \mathrm{~L} \mathrm{~mol} \mathrm{~m}^{-1} \mathrm{~cm}^{-1}\right)^{47}$ as regards the 1,10-phenanthroline (11100L $\left.\mathrm{mol}^{-1} \mathrm{~cm}^{-1}\right)^{47}$, which is the reagent used herein. Despite having increased the method's sensitivity using the bathophenanthroline, the heme was not detected in all samples. 
Another relevant explanation for the nondetection of the heme in the cooked samples is the fact that in the cooking process, depending on the heating temperature ${ }^{43}$ and the meat exposure time, there is the oxidative cleavage of the porphyrin ring the enables the release of iron from the heme complex, increasing thus the quantity of nonheme and $\mathrm{Fe}^{2+}$, as observed in Table 4, in accordance with other published works; ${ }^{37,48}$ and, according to the t-test $(p=0.05)$, all results were statistically different when comparing both preparation manners, evidencing that the variations observed came from the cooking of the samples.

As observed, the cooking process reduces the quantity of heme in the foods, which is known for being the best absorbed form by the organism, but this heating process, among others, is necessary for the food safety and human digestibility.

Thus, many are the reasons for the several differences in the results on the iron speciation in complex samples, which go from the very characteristic of the samples, their preparation procedures, the analysis conditions by the diverse methods, and the choice of the technique to be used.

In summary, the need for information related to the occurrence, distribution and chemical form of elements in biological samples has encouraged the development of analytical methodologies with the objective of determining not only the total content of an analyte but also the chemical speciation.

The determination of chemical species at trace levels in biological samples such as bovine tissue is important because it generates information that helps in solving problems related to nutritional studies. Although the simulation of gastrointestinal digestion fails to reproduce all the physiological and metabolic factors involved in the absorption and utilization of a nutrient in the body, the results presented are referential of how much of the mineral is available to be absorbed, however, in vivo studies are done necessary for a better understanding of the processes involved in the human organism.

\section{Conclusions}

It was verified that among the samples studied, the liver and the heart showed the highest contents of total iron. It could be seen that by cooking the samples, there was an increase in the iron bioaccessibility. The liver and the heart also showed the highest contents of bioaccessible iron contributing respectively with $28 \%$ and $20 \%$ of the total present in the samples. The method used was not sensitive to detect the heme and it was observed that there was a increase of the ionic iron with the cooking due to the release of iron the heme complex.

\section{Acknowledgments}

We thank to the Conselho Nacional de Desenvolvimento Científico e Tecnológico $\mathrm{CNPq}$ - for the Master Degree and the scientific initiation scholarships granted.

\section{References}

${ }^{1}$ Felício, P. D. Valor nutritivo da carne. Available in: $<$ http://www.sic.org.br/PDF/Valornutritivo.p df $>$. Access in: 08 november 2016.

${ }^{2}$ Paiva, A. A; Rondo, P. H. C; GuerraShinohara, E. M. Parameters for the assessment of iron status. Revista de Saúde Pública 2000, 34, 421. [CrossRef] [PubMed]

${ }^{3}$ Yaman, M; Kaya, G. Speciation of iron (II) and (III) by using solvent extration and flame atomic absorption spectrometry. Anaytica Chimica Acta 2005, 540, 77. [CrossRef]

${ }^{4}$ Etcheverry, P; Hawthorne, K. M; Liang, L. K; Abrams, S. A; Griffin, I.J. Effect of beef and soy proteins on the absorption of non-heme iron and inorganic zinc in children. Journal of 
the American College of Nutrition 2006, 25, 34. [CrossRef] [PubMed]

${ }^{5}$ Calheiros, K. O; Canniatti-Brazaca, S. G. Iron availability, protein digestibility and betacarotene amount in alternative formulated of low cost for elderly. Food Science and Technology 2011, 31,41. [CrossRef]

${ }^{6}$ Vieira, R. C. S; Ferreira, H. S. Prevalence of anemia in Brazilian children in different epidemiological scenarios. Brazilian Journal of Nutrition 2010, 23, 433. [CrossRef]

${ }^{7}$ Hurrell, R. F; Reddy, M. B; Juillerat, M; Cook, J. D. Meat protein fractions enhance nonheme iron absorption in humans. Journal of Nutrition 2006, 136, 2808. [PubMed]

${ }^{8}$ Valenzuela, C; Romana, D. L. de; Olivares, M; Morales, M. S; Pizarro, F. Total iron and heme iron content and their distribition in beef meat and viscera. Biological Trace Element Research 2009, 132, 103. [CrossRef] [PubMed]

${ }^{9}$ Lai, J. F; Dobbs, J; Dunn, M.A. Evaluation of clams as a food source of iron: total iron, heme iron, aluminum, and in vitro iron bioavailability in live and processed clams. Journal of Food Composition and Analysis 2012, 25, 47. [CrossRef]

${ }^{10}$ Harrington, C. F; Elahi, S; Merson, S. A; Ponnampalavanar, P. A. A method for the quantitative analysis of iron speciation in meat by using a combination of spectrophotometric methods and highperformance liquid chromatography coupled to sector field inductively coupled plasma mass spectrometry. Analytical Chemistry 2001, 73, 4422. [CrossRef]

${ }^{11}$ Johnston, J; Prynne, C. J; Stephen, A. M; Wadsworth, M. E. Haem and hon.haem iron intake through 17 years of adult life of a British Birth Cohort. British Journal of Nutrition 2007, 98, 1021. [CrossRef] [PubMed]

${ }^{12}$ Quinteros, A; Farré, R; Lagarda, M. J. Optimization of iron speciation (soluble, ferrous and ferric) in beans, chickpeas and lentils. Food Chemistry 2001, 75, 365. [CrossRef]

${ }^{13}$ Cámara, F; Amaro, M. A; Barberá, R; Lagarda, M. J. Speciation of bioacessible (heme, ferrous and ferric) iron from school menus. European Food Research and Technology 2005, 221, 768. [CrossRef]

${ }^{14}$ Promchan, J; Shiowatana, J. A dynamic continuous-flow dialysis system with on-line electrothermal atomic absorption spectrometric and $\mathrm{pH}$ measurements for invitro determination of iron bioavailability by simulated gastrointestinal digestion. Analytical and Bioanalytical Chemistry 2005, 382, 1360. [CrossRef]

${ }^{15}$ Pongrac, P.; Scheers, N.; Sandeberg, A-S.; Potisek, M.; Arčon, I.; Kreft, I.; Kump, P.; Vogel-Mikuš, K. The effects of hydrothermal processing and germination on Fe speciation and Fe bioaccessibility to human intestinal Caco-2 cells in Tartary buckwheat. Food Chemistry 2016, 199, 782. [CrossRef]

${ }^{16}$ Turhan, S; Ustun, N. S; Altunkaynak, T. B. Effect of cooking methods on total and heme iron contents of anchovy (Engraulis encrasicholus). Food Chemistry 2004, 88, 169. [CrossRef]

${ }^{17}$ Singh, A.; Bains, K.; Kaur, H. Effect of inclusion of key foods on in vitro iron bioaccessibility in composite meals. Journal of Food Science and Technology 2016, 53, 2033. [CrossRef]

${ }^{18}$ Lopes, C. G. Deficiência de ferro na alimentação humana. Available in: <http://www.acessa.com/viver/arquivo/nutri cao/2003/03/7-Cristina/>. Access in: 08 november 2016.

${ }^{19}$ Ramos, A; Cabrera, M. C. Bioaccessibility of $\mathrm{Se}, \mathrm{Cu}, \mathrm{Zn}, \mathrm{Mn}$ and $\mathrm{Fe}$, and heme iron content in unaged and aged meat of Hereford and Braford steers fed pasture. Meat Science 2012, 91, 116. [CrossRef] [PubMed]

${ }^{20}$ Puchas, R. W; Busboom, J. R; Wilkinson, B. Changes in the forms of iron and in concentrations of taurine, carnosine, coenzyme Q10 and creatine in beef longissimus muscle with cooking and simulated stomach and duoedenal digestion. Meat Science 2006, 74, 443. [CrossRef] [PubMed]

${ }^{21}$ Williams, P. Nutritional composition of red meat. Nutrition \& Dietetics. 2007, 64, S113. [CrossRef]

${ }^{22}$ Cabrera, M. C; Ramos, A; Saadoun, A; Brito, G. Selenium, copper, yinc, iron and 
manganese content of seven meat cuts from Hereford and Braford steers fed pasture in Uruguay. Meat Science 2010, 84, 518. [CrossRef] [PubMed]

${ }^{23}$ Lombardi-Boccia, G; Lanzi, S; Aguzzi, A. Aspects of meat quality: trace elements and $B$ vitamins in raw and cooked-meats. Journal of Food Composition and Analysis 2005, 18, 39. [CrossRef]

${ }^{24}$ Valle, E. R. do. Carne bovina: alimento nobre e indispensável. Available in: <http://www.alice.cnptia.embrapa.br/handle /doc/325245>. Access: 05 november 2016.

${ }^{25}$ Han, D; McMillin, K. W; Godber, J. S. Hemoglobin, myoglobin, and total pigments in beef and chicken muscles: chromatographic determination. Journal of Food Science 1994, 59, 1279. [CrossRef]

${ }^{26}$ Bahar, S; Zakerian, R. Speciation of Fe(II) and $\mathrm{Fe}(\mathrm{III})$ by using dispersive liquid-liquid microextraction and flame atomic absorption spectrometry. Journal of the Brazilian Chemical Society 2012, 23, 944. [CrossRef]

${ }^{27}$ Kafaoglu, B.; Fisher, A.; Hill, S.; Kara, D. Determination and evaluation of element bioaccessibility in some nuts and seeds by invitro gastro-intestinal method. Journal of Food Composition and Analysis 2016, 45, 58. [CrossRef]

${ }^{28}$ De Brier, N.; Gomand, S. V.; Donner, E.; Paterson, D.; Smolders, E.; Delcour, J. A.; and Lombi, E. Element distribution and iron speciation in mature wheat grains (Triticum aestivum $\mathrm{L}$.) using synchrotron $\mathrm{X}$-ray fluorescence microscopy mapping and $X$-ray absorption near-edge structure (XANES) imaging. Plant, Cell \& Environment 2016, 39, 1835. [CrossRef]

${ }^{29}$ Stelmach, E.; Szymczycha-Madeja, A.; Pohl, P. A simplified determination of total concentrations of $\mathrm{Ca}, \mathrm{Fe}, \mathrm{Mg}$ and $\mathrm{Mn}$ in addition to their bioaccessible fraction in popular instant coffee brews. Food Chemistry 2016, 197, 388. [CrossRef]

${ }^{30}$ Kaasalainen, H.; Stefánsson, A.; Druschel, G. K. Determination of Fe (II), Fe (III) and Fe total in thermal water by ion chromatography spectrophotometry (IC-Vis). International Journal of Environmental Analytical Chemistry 2016, 96, 1074. [CrossRef]
${ }^{31}$ Gotti, R.; Fiori, J.; Liverani, L.; Spelta, F. Capillary electrophoresis method for speciation of iron (II) and iron (III) in pharmaceuticals by dual precapillary complexation. Electrophoresis 2015, 36, 2820. [CrossRef]

${ }^{32}$ Kozak, L.; Niedzielski, P.; Wachowiak, W. The tandem analytical method of flow injection diode array spectrophotometry and flame atomic absorption spectrometry (FIDAD (vis)-FAAS) in iron speciation studies using 1, 10-phenanthroline complexes. Microchemical Journal 2013, 110, 54. [CrossRef]

${ }^{33}$ Ribani, M; Bottoli, C. B. G; Collins, C. H; Jardim, I. C. S. F. Validation for chromatographic and electrophoretic methods. Química Nova 2004, 27, 771. [CrossRef]

${ }^{34}$ Agência Nacional de Vigilância Sanitária (ANVISA); Guia para Validação de Métodos Analíticos e Bioanáliticos, RE $\mathrm{n}^{\circ} 899$, de 29 de maio de 2003. [Link]

${ }^{35}$ Inmetro. Orientação sobre validação de métodos de ensaios químicos (2003). DOQCGCRE-008, revisão 02 - junho/2007. [Link]

${ }^{36} \mathrm{Krug}$, F. J. Métodos de preparo de amostras; fundamentos sobre preparo de amostras orgânicas e inorgânicas para análise elementar. CENA/USP: Piracicaba, 2008.

${ }^{37}$ Lombardi-Boccia, G; Martnez-Domnguez, B; Aguzzi, A; Rincon-Leon, F. Optimisation of heme iron analysis in raw and cooked meat. Food Chemistry 2002, 78, 505. [CrossRef]

${ }^{38}$ Carpenter, C. E; Clark, E. Evaluation of methods used in meat iron analysis and iron content of raw and cooked meats. Journal of Agricultural and Food Chemistry 1995, 43, 1824. [CrossRef]

${ }^{39}$ Kalpalathika, P. V. M; Clark, E. M; Mahoney, A. W. Heme iron content in selected ready-to-serve beef products. Journal of Agricultural and Food Chemistry 1991, 39, 1091. [CrossRef]

${ }^{40}$ Site of RGNUTRI. Carne vermelha: propriedades nutricionais. Available in: <http://www.rgnutri.com.br/>. Access em: 08 november 2016.

${ }^{41}$ Site of INMETRO. Carne bovina e suína: teor de gordura e colesterol em alimentos. 
Available

<http://www.inmetro.gov.br/consumidor/pr

odutos/teorGordura.asp>. Access: 07 november 2016.

${ }^{42}$ Momm, R.C; Coelho, M.A. Elaboração de produtos de salsicharia utilizando Proteína miofibrilar extraída de miúdos de suíno e Bovino (coração). Revista Caminhos 2006, 7, 69. [Link]

${ }^{43}$ Han, D; McMillis, J. S; Godber, T. D; Younathan, M. T; Marshall, D. L; Hart, L. T. Iron distribution in heated beef and chicken muscles. Journal of Food Science 1993, 58, 697. [CrossRef]

${ }^{44}$ Miret, S.; Simpson, R.; Mckie, A. T. Physiology and molecular biology of dietary iron absorption. Annual Review of Nutrition 2003, 23, 283. [CrossRef] [PubMed] in: ${ }^{45}$ Sandstrom, B. Micronutrient interactions: effects on absorption and bioavailability. British Journal of Nutrition 2001, 85, S181. [CrossRef] [PubMed]

${ }^{46}$ Feijó, G. L. D. Curso: conhecendo a carne que você consome. Qualidade da carne bovina. Campo Grande: Embrapa Gado de Corte, 1999. 25p. [Link]

${ }^{47}$ Rocha, F. R. P; Teixeira, L. S. G. Strategies to increase sensitivity in UV-vis spectrophotometry. Química Nova 2004, 27, 807. [CrossRef]

${ }^{48}$ Kongkachuichai, R; Napatthalung, P; Charoensiri, R. Heme and nonheme iron content of animals products commonly consumed in Thailand. Journal of Food Composition and Analysis 2002, 15, 389. [CrossRef] 